\title{
DEIXA AKO PROSTRIEDOK AKTUALIZÁCIE CYRILO-METODSKEJ TÉMY V ÚVODE KÁZNE JURAJA FÁNDLYHO
}

\section{The Deictic Expressions in Updating the Theme of the Cyril and Methodius Mission in the Beginning of the Sermon Written by Juraj Fandly}

\author{
Gabriela Mihalková
}

DOI: 10.17846/CL.2020.13.1.167-176

\begin{abstract}
MIHALKOVÁ, Gabriela. The Deictic Expressions in Updating the Theme of the Cyril and Methodius Mission in the Beginning of the Sermon Written by Juraj Fandly. The subject of the study is the analysis of the use of deictic expressions in the beginning of the sermon written by Juraj Fándly Concio Historico - Panegyrica de Sanctis Slavorum Apostolis, Cyrillo, \& Methodio dedicated to Saint Constantine and Methodius, published as part of the two-volume edition of Fándly's Príhodné Swátečné Kázňe (Trnava 1795 - 1796). Attention is focused on the area of personal and temporal deixis, on the analysis of means by which the sermon refers to the participants of the communication and their status, role and actual present situation. The study asks whether there is a correlation between the compositional division of sermon and the distribution of deictic expressions, and how deixis participates in the process in which the subject of the Cyrillo-Methodian mission becomes an actual part of the obedient lecture-oriented discourse.
\end{abstract}

Key words: deixis, sermon, Constantine and Methodius, Juraj Fándly

\begin{abstract}
Abstrakt: MIHALKOVÁ, Gabriela. Deixa ako prostriedok aktualizácie cyrilo-metodskej témy $v$ úvode kázne Juraja Fándlyho. Predmetom štúdie je analýza použitia deiktických prostriedkov v úvode príležitostnej kázne Juraja Fándlyho Concio Historico - Panegyrica de Sanctis Slavorum Apostolis, Cyrillo, \& Methodio venovanej pamiatke svätého Cyrila a svätého Metoda, ktorá vyšla tlačou ako súčast dvojzväzkového vydania Fándlyho kázní Príhodné Swátečné Kázňe (Trnava 1795 - 1796). Pozornost' sa sústredí na oblast personálnej a sociálnej deixy, teda na analýzu prostriedkov, pomocou ktorých sa v kázni odkazuje na účastníkov komunikácie a ich status, rolu, vztah. Štúdia si kladie otázku, či existuje korelácia medzi kompozičným členením kázne a distribúciou deiktických prostriedkov a ako sa deixa podiela na procese, pri ktorom sa téma cyrilo-metodskej misie stáva aktuálnou súčastou kazatelského diskurzu orientovaného na poslucháčov.
\end{abstract}

Klúčové slová: deixa, kázeň, cyrilo-metodská misia, Juraj Fándly

Podstatnú rolu pri formovaní národného povedomia na Slovensku na konci 18. storočia a v priebehu 19. storočia zohrávalo exponovanie minulosti ako potvrdzovanie kontinuálnej existencie národa, dialo sa tak v najrozmanitejších slovesných útvaroch, od populárno-náučnej literatúry až po beletriu, v žánroch ako historické kompendium, epos, óda, historická próza, kázeň. Príspevok sa bude venovat tematizácii cyrilo-metodskej misie v úvode kázne Juraja Fándlyho 
Concio Historico - Panegyrica de Sanctis Slavorum Apostolis, Cyrillo, \& Methodio so zameraním na otázky personálnej, sociálnej a časopriestorovej deixy, teda na otázky, akým spôsobom sa ukazuje na účastníkov komunikácie (kazatela a jeho poslucháčov), ich status, rolu, vztah, a na neučastníkov komunikácie, a teda na tých, o ktorých sa hovorí, na svätého Cyrila a Metoda, ako sa používajú deiktické prostriedky vo vztahu k historickým osobnostiam, či časová dištancia medzi účastníkmi komunikácie (kazatel' a poslucháči) a tými, o ktorých sa hovorí, svätým Cyrilom a Metodom, ovplyvňuje podobu použitých deiktických prostriedkov. ${ }^{1}$ Výsledky analýzy úvodu kázne Juraja Fándlyho budú v závere porovnané s kázňami Jána Kollára a Jonáša Záborského, ktorí sa tiež, hoci v ovela menšom rozsahu, venovali cyrilo-metodskej tematike.

Bernolákovec, člen Slovenského učeného tovarišstva, dlhoročný farár v Naháči, autor populárno-náučnej a kazatel'skej literatúry, Juraj Fándly (1750 - 1811) vydal v rokoch 1795 - 1796 Príhodné a Swátečné Kázňe ${ }^{2}$ v dvoch zväzkoch, a prítomnost̉ deiktických prostriedkov, ich distribúciu a funkčnost̉ budeme analyzovat na materiáli kázne nazvanej Concio Historico - Panegyrica de Sanctis Slavorum Apostolis, Cyrillo, \& Methodio, ktorá bola zaradená do 2. zväzku zbierky Príhodné Swátečné Káž̌e (1796). Kázeň vychádza z historickej problematiky, no zameriava sa predovšetkým na otázku cyrilo-metodského dedičstva, teda na možnosti aktualizácie historickej témy, na obrodenecký, motivačný, aktivizačný potenciál historickej témy pre Fándlyho súčasníkov. Úspešnost' kázne spočíva $\mathrm{v}$ schopnosti nadviazat dialóg s adresátom. Persuazívna stránka kázne sa prejavuje v logickosti výstavby, presviedčaní, zhromažd’ovaní dôkazov a ich sprostredkúvaní prijatelnou, zrozumitelnou a zaujímavou formou poslucháčom. Nepochybne ide o žáner, kde podstatnú rolu pri koncipovaní textu zohrávajú komunikační partneri - kazatel’ a jeho poslucháči. V samotnom texte kázne sa na participantov komunikačnej situácie odkazuje prostredníctvom zámen (JA, TY, MY alebo VY), 1. a 2. slovesnej osoby. ${ }^{3}$

Kázeň Juraja Fándlyho Concio Historico - Panegyrica de Sanctis Slavorum Apostolis, Cyrillo, \& Methodio bola viacnásobne analyzovaná z literárnovedných hladísk (literánohistorické, genologické, tematické, kompozičné špecifiká kázne) a z jazykovedných pozícií (predovšetkým štylistické, lexikálne špecifiká), no zatial’ sa nevenovala pozornost’ uplatneniu deiktických prostriedkov v kázni, ich vztahu ku kompozícii a téme kázne.

Nadpis kázne Concio Historico - Panegyrica de Sanctis Slavorum Apostolis, Cyrillo, \& Methodio obsahuje žánrové, architextuálne ${ }^{4}$ (concio) a bližšie typologické určenie (Historico - Panegyrica)

Príspevok vznikol v rámci grantového projektu VEGA 1/0099/16 Personálna a sociálna deixa v jazyku (človek v jazyku, jazyk o človeku).

2 V príspevku budeme používat diplomatický prepis pôvodných textov.

3 Vztahovanie výpovede $\mathrm{k}$ partnerom komunikácie prostredníctvom systému osobných zámen a volby slovesnej osoby rieši personálna deixa. 1. osoba singuláru vyjadruje situáciu priamej účasti hovoriaceho na rozprávanom, 2. osoba adresáta a 3. osoba toho alebo to, o čom sa hovorí, teda situáciu neúčasti. Kým jednotlivo JA a TY identifikujú spravidla účastníkov komunikácie jednoznačne a individuálne, MY zahŕňa hovoriaceho aj adresáta výpovede a má tri rôzne podoby: MY znamená inkluzívne JA a TY/VY, ked' singulárny hovoriaci reprezentuje dvojicu alebo skupinu z pozície jej člena; MY znamená exkluzívne JA a ostatní so mnou okrem teba/vás alebo MY vystupuje ako štylizácia singulárneho subjektu (autorský plurál), ako všeobecný subjekt vo formuláciách inštrukcií, návodov, pravidiel (Hirschová 2013, 97-98).

4 Architextualita, jeden z piatich typov transtextuálnych vztahov vymedzených G. Genettom (1997, 4), označuje text ako súčast žánru v titule alebo podtitule a vychádza z tézy, že text neustále odkazuje na všeobecne platné pravidlá, na základe ktorých je skonštruovaný. Fándlyho odkaz na žáner v nadpise (Concio) sa reflektuje hned'v úvode, kde sa hovorí vo všeobecnosti o kazatelovi a kázni, no dalej sa častejšie používa žánrové pomenovanie reč, prípadne chwáloreč (Fándly 1796, 457). Uprednostnením žánru reči pred kázňou Fándly zvýrazňuje odklon od primárne náboženského obsahu (kázeň) a príklon k národnému, ideologickému charakteru prejavu (reč). 
textu ako historickej chváloreči tematicky zameranej na oslavu svätých apoštolov Slovanov, Cyrila a Metoda. Po nadpise nasleduje textus, najprv v latinčine: „Laudemus Viros gloriosos, \& Parentes nostros, in generatione sua. Eccl. 44. v. I.“, a potom v bernolákovskej slovenčine: „Wichwalugme Mužow chwalitebních, a Predkow naších, w Pokoleňú swém." (Fándly 1796, 447). Textus, tvorený biblickým výrokom, uvádza kázeň, tematicky s ňou súvisí. Názvom avizovaný panegyrický obsah reči sa tu explikuje verbom Wichwalugme a adjektívom chwalitebních, historický obsah substantívom Predkow. Textus okrem tematickej anticipácie reči obsahuje aj deiktické prostriedky ukazujúce na účastníkov komunikácie. Kedže ide o citát, je potrebné uvažovat’ o minimálne dvoch kontextoch použitia deiktických prostriedkov, najskôr v prototexte a následne v metatexte kázne. V prototexte, v starozákonnej Knihe Sirachovcovej (Ecclesiasticus) sa vo verši: „Chválit nám patrí slávnych mužov, svojich otcov podla ich činov" Sir 44, 1 (Sväté pismo 2007, 1276-1277) prostredníctvom slovesnej osoby a zámena (Chválit nám patrí) vyjadruje inkluzívne MY, ked’ singulárny hovoriaci reprezentuje dvojicu alebo skupinu z pozície jej člena, MY zahŕňa JA, autora Knihy Sirachovcovej, Jezua, a VY, vyvolený izraelský národ. V metatexte Fándlyho už deiktické prostriedky ukazujú na participantov aktuálnej komunikačnej situácie vytváranej kázňou. Prostredníctvom zámena naších sa vyjadruje inkluzívne MY, ktoré zahŕňa JA a VY, pričom JA ukazuje na aktuálne hovoriaceho, na kazatel’a a VY na adresátov kázne, ich spojivom, inkluzívnym faktorom je spoločná minulost' (Predkow naších). Verbom Wichwalugme sa vyjadruje očakávaná aktivita na strane produktora textu, ale aj adresáta, ide o inkluzívny autorský plurál. Verbom anticipovaná aktivita sa následne realizuje kázňou.

\section{Exordium v reči Juraja Fándlyho}

Exordium vo Fándlyho reči pozostáva $z$ troch odsekov odlišného zamerania, prvý je zameraný na samotný proces prípravy kázne a vyjadruje záujem kazatela zaujat svojho poslucháča. Zamyslenie v úvodnom odseku reči končí Juraj Fándly výrokom týkajúcim sa aktuálnej komunikačnej situácie (dňešná Kázeñ) a jej participantov, autora a adresátov: „Bár táto mogá dňešná Kázeň ňebude ozdobená s Krásu Wimluwností, nazdáwám sa predca, že wám bude wzácná preto, že gest o nowém, wám ešč ňeznámém Predsewzatú priprawená." (Fándly 1796, 448). Autor je vo výpovedi deikticky sprítomnený zámenom (mogá) a verbom (nazdáwam sa), ktorým vyjadruje istú mieru subjektivity a (ne)istoty, ked' ako autor odhaduje, predpokladá, ako bude jeho reč prijatá poslucháčmi. Autorské usúvztažnenie sa so svojou výpovedou (mogá dňešná Kázeň) sa deje z pozície skromnosti (řebude ozdobená s Krásu Wimluwnostî). Nie štylistická bravúra autora, ale novost témy má oslovit adresátov kázne, na ktorých ukazuje vo vete dvakrát prítomné pronomen wám. Kázeň teda na konci 18. storočia pripravuje Juraj Fándly pre publikum, ktoré dejiny cyrilo-metodskej misie nepozná a hodnota kázne sa zakladá na sprístupnení nových poznatkov. Vo formuláciách je zjavná nadradenost̉ JA - kazatel’a voči adresátom z hladiska množstva vedomostí, kazatel' sa pripravuje sprostredkovat poslucháčom tému, o ktorej nepočuli.

Exordium predstavuje priestor na sformulovanie, zdôvodnenie témy (funkcia propozície) a zámeru (intencie) reči, na biblickú a tiež historickú kontextualizáciu, teda na nájdenie súvislostí medzi témou reči a biblickým rozprávaním, na nájdenie prvkov kontinuity, biblických a historických predchodcov činnosti svätého Cyrila a Metoda až po aktualizačný rozmer výpovede v jej zameraní na súčasnú aktivitu participantov komunikačnej situácie a jej modelovanie, anticipovanie smerom do budúcnosti: „S Počtu apoštolskích Námestňikow, kterí po mnohích Kragnách Sweta tehoto, w Bludu pohanském rozprchnuté a potratené Duše, s welkím Unowáním, w Potu Twári swég wihledáwali, a častokrátním Učeñím katolíckég Wíri do Owčinca kristowého priwádzali, sú aj títo dwa dňešní apoštolskí, chwalitební Mužowé, swatí Ciril, swatí Method, na kterích Čest', a Chwálu, 
wi ste sa wčil semkag pobozno zešli, aby sté gím swátečnu Slawnost’ preukázalì, abi ste Boha, ai gích $z$ wašíma Modlitbámi wichwalowali, gakožto duchowních Predkow, a w Pokoleňú swém, nagwatších Apoštolow." (Fándly 1796, 449-450). Citovaná veta obsahuje viaceré deiktické prostriedky, jedny (gím) ukazujú na tých, o ktorých sa hovorí (svätý Cyril a Metod), dalšie pomocou indexu VY (wi), posesívneho tvaru zámena VÁŠ ( $z$ wašíma Modlitbámi) či slovesnej osoby (ste sa ... zešli; aby ste ... preukázali; ste ... wichwalowali) ukazujú na tých, ku ktorým sa hovorí, výpoved’ sa tu vztahuje výlučne na adresátov reči. Fándly ako komunikátor hovorí o zámere komunikantov vyjadrit úctu, chválu svätému Cyrilovi a Metodovi, ktorých výnimočné postavenie dokladá ich zaradením hned' za Boha (Boha, ai gích), o rozmere ich idealizácie vypovedá použitie superlatívu (nagwatších). Vysokú mieru aktuálnosti kázne potvrdzuje časopriestorová deixa, indexami TERAZ a TU (wčil semkag) sa situuje komunikačná situácia v relácii k jej participantom do bezprostrednej prítomnosti, práve sa odohrávajúcej v priestore udalosti, ked’ sa hovorí, v priestore a čase zdielanom participantmi komunikácie. Časová deixa ${ }^{5}$ sa vztahuje jednak na participantov komunikácie (ste sa wčil ... zešlì), jednak na to, o čom sa hovorí (títo dwa dňešní apoštolskí, chwalitební Mužowé). Indexový lexikálny prostriedok TERAZ, DNES je determinovaný kontextom výpovede, určuje referenčný bod temporality, od ktorého sa situačne hodnotia ostatné udalosti ako minulé alebo ako budúce. Vo Fándlyho reči sa formuluje ako podstatné vedomie kontinuity od čias pôsobenia Cyrila a Metoda až do súčasnosti: „switol naším starodáwním pohanskím Slowákom, dluhí, aš dowčilka trwagící gasní Ďeñ, našég spasitelnég katolickég Wíri, na kteru, gích títo dwa swatí Učitelì obrátili. “" (Fándly 1796, 450). Slovné spojenie dowčilka trwagící poukazuje na pretrvávajúci účinok misie Cyrila a Metoda do súčasnosti, pričom atribút aktuálnosti sa vztahuje na prebiehajúcu komunikačnú situáciu. Na aktuálnych participantov komunikácie ukazujú tvary zámena NÁŠ (naším, našég), vyjadrujúce zdiel’anie, spoluúčast', kazatel’ sa spolu s poslucháčmi prihlási k Slovákom ako k svojim predkom, vyznávačom katolíckej viery, a zvýrazní tak kontinuitu. Naopak, tvary zámena ONI (gích) sa vztahujú na neúčastníkov komunikácie, na Slovákov pokrstených Cyrilom a Metodom v prípade, že sa komunikuje o minulej, uzavretej udalosti.

Juraj Fándly po usúvztažnení predkov so súčasníkmi prenesie pozornost’ poslucháčov na minulost' so zámerom priblížit im veci historické ako také, ktoré sa ich aj v prítomnosti dotýkajú. Zmení adresáta svojej reči, naruší dištanciu medzi minulostou a prítomnostou a bezprostredne osloví starodávnu slovenskú krajinu, stratifikovanú prostredníctvom hydroným (Morava, Hron): „Blahoslawená si bola od Boha! starodáwná, welká slowenská, welká morawská Kragina“ (Fándly 1796, 451). Následne viacnásobne použité TY (pre teba, tebe, twogé) neukazuje na fyzicky prítomného poslucháča reči, ale virtuálnym adresátom, komunikačným partnerom Fándlyho sa stala krajina synekdochicky zastupujúca predkov Slovákov. Po oslovení krajiny sa adresát výpovede opät zmení, prostredníctvom VY sú oslovení svätci: „Blahoslawení ste wi naší swatí Apoštoli, že stee w našém slowenském Národu wašé apoštolské Práce tak ščastlïwe konali““ (Fándly 1796, 451). Okrem VY sa tu a aj dalej využíva MY, ktoré má exkluzívny charakter, čo znamená, že MY (JA a ostatní so mnou, príslušníci slovenského národa) sa vyhraňuje oproti VY, oproti Cyrilovi a Metodovi, pričom nejde o vylúčenie, dištanciu, ale vztah zverenstva, slovenský národ sa zveruje Cyrilovi a Metodovi.

V závere exordia sa kazatel' vyjadrený explicitným JA $(g a)$ a posesívnym tvarom zámena (mogích) opät obracia na Cyrila a Metoda ako adresátov svojej reči, na ktorých ukazujú tvary zámena (wás, waších) a upriamuje pozornost’ na realizáciu prejavu: „gedno Ňeščastí na wás, ai na tíchto mogích prítomních Poslucháčow, waších pobožních Ctitelow nachádzám, totíšto: že sem

5 Časová deixa sa realizuje deiktickými designátormi (gramémy ako derivačné sufixy slovesných tvarov i vidové významy, syntaktické konštrukcie /bude, je, bol/, temporálne adverbiálne výrazy, predložky) a indexovými lexikálnymi prostriedkami (teraz, dnes, včera, zajtra) (Hirschová 2013, 77-83). 
gá pri tégto dňešnég Slawnosti, na túto Kazatelňicu wistúpil, kterého Sílu, a Wimluwnosti mogég Krásu, wašé swaté apoštolské Práce, wašá Chwála, len welmi welice prewišuge, a že mňe téš tégto uloženég Hodini krátki Čas ňedopuščá, abich mohol wašé chwalitebné a swaté Zásluhi len na krátko spomenut', nebo dostatečne wichwalowat." (Fándly 1796, 452). Fándly zdôrazňuje verbálny rozmer svojho prejavu prostredníctvom slova Poslucháčow a napriek písomnej realizácii reči, zvýraznenej bohatým poznámkovým aparátom odkazujúcim na vtedajšiu dostupnú literatúru venovanú vel'komoravskej problematike, sám seba označuje za hovoriaceho: „Poňewáč ale, ňeprehlídagíce títo Wímluwi, gá predca mluwit musím, prosím nagmilegší Poslucháči, ňech wám gest wdačná moga Prosba, ai táto dňešná Reč, gá s ňú, a wi s túto wašú Pobožnostưu," (Fándly 1796, 453). Fándly explikuje žánrové zaradenie textu (Reč) a v situácii komentovania komunikačnej situácie výslovne pomenúva jej participantov, na seba ako autora ukazuje priamo zámenom JA a na adresátov VY. Ak d’alej hovorí o spoločnej aktivite, téme, použije MY: „tak gednomiselné, spolu wichvalugme tíchto swatích Mužow, chwalitebnich a duchowních Predkow naších v Pokoleňú našém. Máme Príčinu tégto Chváli, w tég welikég Pobožnosti kteru gím ňebohá naggasňeǧsá (ščastliwe panugícá) Králowna naša, po títo pominuté Roki preukazovala, a spolu z Dowoleňím swatég rimskég Stolici, na tento dňešní Ďeň, s takúto Pobožnostú, z bozskími Službámi zachowáwat porúčila, o čem abi ste mna l’epši wirozumeli, merkugte na toto, tégto dňešnég mogég Reči Predsewzatí." (Fándly 1796, 453). V poslednej vete exordia sa používa 2 . slovesná osoba plurálu v prípade inštruovania poslucháčov (abi ste mna lepš̌i wirozumeli) a formulovania výzvy (merkugte). Fándlymu ako kazatelovi záleží na obsahu a forme reči, lebo má viest’ k upevneniu národného povedomia a k pochopeniu dôležitosti cyrilo-metodskej misie pre Slovákov.

\section{Predsewzati' - druhá kompozičná čast' úvodu reči Juraja Fándlyho}

V časti reči Juraja Fándlyho nazvanej Predsewzatí sa objavujú deiktické prostriedky ukazujúce na participantov komunikačnej situácie predovšetkým v podobe MY (desatkrát), menej VY (osemkrát) a najmenej JA (dvakrát), vôbec sa nevyskytuje TY.

Najčastejší tvar MY v Predsewzatí má podobu privlastňovacieho zámena NÁŠ, ktoré sa používa dvojako: na vyjadrenie vzţahu kazatela a poslucháčov k Cyrilovi a Metodovi: „duchowní Predkowé naši“, „naší nagwatši duchowní Pastíri“, „našich welkích SS. Patronow“, „naších nagvatších a prwňích Biskupow" (Fándly 1796, 454-455) a na vyjadrenie príslušnosti kazatela, poslucháčov k národnému spoločenstvu vyznačujúcemu sa dlhou históriou a kontinuitou: „pre Spaseňí našého slowenského Národu“, „w našém slowenském Pokoleñü“, „náš slawní Národ“, „našich prwñích katolíckích Slowákow“ (Fándly 1796, 453-455). Dominancia tvarov zámena NÁŠ v tejto časti reči znamená, že formulácie predsavzatia sa vztahujú na všetkých, čo sa zúčastňujú komunikačnej situácie ustanovenej rečou, na jej tvorcu, príjemcov, ale aj všeobecnejšie na všetkých príslušníkov národného spoločenstva. Explicitná deixa „sme mi Slowáci“ (Fándly 1796, 455) podčiarkuje nacionálne zacielenie kázne, index $m i$ v spojení so substantívom Slowáci nespochybnitelne národne identifikuje autora spolu s adresátmi. Fándlym želané dosiahnutie uvedomenia si participácie, spoluúčasti na národnom spoločenstve sa pretavilo do preferencie deiktického MY v tejto časti reči.

Druhá slovesná osoba plurálu sa používa v spojení s procesmi kognície, uchovávania poznatkov („pamatagte“, metaforicky „w Srdcách waších zachowáwagte"), percepcie („počuwat budete“, „počuwagte“), v spojení s dosiahnutím želaného stavu („abi ste ai wi nagmilegši Poslucháči, blaboslawení boli“") (Fándly 1796, 455). Vo všetkých prípadoch ide o orientáciu na požadovanú budúcu aktivitu/situáciu poslucháčov, ktorí sú autorom explicitne oslovení prostredníctvom VY. $\mathrm{Na}$ autora samotného sa $\mathrm{v}$ Predsewzatí ukazuje len dvakrát v súvislosti s aktuálnou rečou a prebiehajúcou situáciou: „mogeg Reči“, „mna [...] počúwagte“" (Fándly 1796, 455). Najdominantnejšie sa 
v Predsewzatí referuje o vztahu, najvyššie zastúpenie z deiktických prostriedkov majú tvary privlastňovacieho zámena NÁŠ. Z početnosti výskytu je zrejmá dôležitost̉ vyjadrenia inkluzívneho vztahu participantov komunikácie a popri očakávanom vysokom zastúpení 3. os. plurálu, kedže sa kázeň orientuje na výpoved’ o nich, o Cyrilovi a Metodovi, sa rovnako početne uplatňuje aj 2. os. plurálu, čo zjavne vyplýva zo zamerania Fándlyho na poslucháčov, funkciou Predsewzatí nie je vyjadrenie singulárnych autorských zámerov, ale vyvolanie odozvy na strane adresátov.

\section{Výsledky analýzy úvodu Fándlyho reči}

Z kompozičného hladiska zvolil Juraj Fándly v reči Concio Historico - Panegyrica de Sanctis Slavorum Apostolis, Cyrillo, \& Methodio výrazné členenie, použil viacero formálnych prostriedkov na zvýraznenie architektoniky reči - nadpisy, medzery, odseky a deiktické prostriedky sa kumulovali práve na hraniciach jednotlivých kompozičných jednotiek. Personálna deixa ako ukazovanie na komunikačných partnerov má v úvode reči Juraja Fándlyho konštantné riešenie, rola vypovedajúceho je pridelená výlučne kazatelovi, ukazuje naňho 1 . osoba singuláru a 2. osoba prevažne plurálu identifikuje adresátov reči - poslucháčov. ${ }^{6} \mathrm{~V}$ úvode absentujú slovesá $\mathrm{v} 2$. osobe singuláru (okrem jedinej výnimky), čo potvrdzuje formulovanie výpovede ako príhovoru k spoločenstvu, nie $\mathrm{k}$ jednotlivcovi. Z hladiska použitých slovesných osôb v celom úvode Fándlyho reči dominuje 3. osoba singuláru (použitá 47-krát) nasledovaná 3. osobou plurálu (použitá 21-krát), potom v súlade s orientáciou reči na poslucháča nasleduje 2. osoba plurálu (použitá 13-krát), vlastnú aktivitu komentuje Juraj Fándly v 1. osobe singuláru (8-krát), najnižšie zastúpenie má 1. osoba plurálu (4-krát) a 2. osoba singuláru (1-krát). Početnost' výskytu slovesných osôb sa v rámci jednotlivých častí úvodu samozrejme líši, napríklad v Predsewzatí nedominuje 3. osoba singuláru, ale 3. osoba plurálu, odkazujúca na aktivitu svätého Cyrila a Metoda a vtedajších Slovákov, nasledovaná 2. osobou plurálu zvýrazňujúcou orientáciu Predsewzatí na dosiahnutie efektu na strane poslucháčov. V exordiu predstavuje v použitých slovesných osobách odchýlku tretí, posledný odsek, v ktorom má výrazné zastúpenie, kedže vyjadruje autorské postoje, 1. osoba singuláru.

Zásadne inak než slovesné osoby sa v úvode Fándlyho reči distribuovali deiktické prostriedky v podobe zámen, na prvých dvoch miestach vo všetkých častiach úvodu alternovalo MY a VY, až potom nasledovali ON/ONI a JA, len marginálne zastúpenie malo TY. Ak sa výpoved’ vztahovala výlučne na adresátov reči, používal sa tvar zámena VY/VÁŠ, no ak sa výpoved’ vztahovala na celé spoločenstvo, bola všeobecnejšia, používal sa tvar zámena MY/NÁŠ, ktoré inkluzívne vypovedá o spoluúčasti JA a VY na tom, o čom sa hovorí. Inkluzívne chápanie MY, spojenie autora a jeho poslucháčov do jednej skupiny sa v úvode reči Juraja Fándlyho tvorilo vd’aka spoločnej minulosti, vdaka príslušnosti k rovnakému národnému a jazykovému spoločenstvu a k rovnakej konfesii. Konkrétne z hladiska prítomnosti posesívnych zámen sa snaha Fándlyho usúvzṫažnit historickú tému so súčasnostou poslucháčov reči prejavila v najvyššej frekvencii tvaru NAŠI.

Významným spôsobom sa na aktuálnom vyznení reči Juraja Fándlyho podielajú časové deiktické prostriedky. Situovanost’ výpovede na temporálnej osi (dňešní deň) sa viaže na uskutočňovanú komunikačnú situáciu (dňešná Kázeň, dňešná Reč, dňešnég mogeg Reči), to, o čom sa vypovedá, je rovnako aktuálne ( $d w a$ dňešní apoštolskí, chwalitební Mužowé, swatí Ciril, swatí Method). Vysoká frekvencia výskytu slova dřešní v úvode reči dokladá snahu Fándlyho podat tému cyrilo-metodskej misie nielen ako tému historickú, ale aj ako tému, ktorá patrí do aktuálnej doby poslucháčov. Transfer medzi rozpravou o minulosti a súčasnou komunikačnou situáciou sa

6 Kým rola vypovedajúceho subjektu je vzhladom na monologický charakter kázne konštantná, nemenná, adresát prehovoru sa v jednom odseku exordia zmenil, kazatel' oslovil krajinu a potom Cyrila a Metoda. 
verbalizuje prostredníctvom časovej deixy TERAZ, DOTERAZ, v úvode reči sú výrazy ako wčil semkag, dowčilka trwagíci, we wčilagšém Časi, wčilagšeg Morawi prítomné v kontexte vyjadrujúcom pretrvávanie následkov minulej udalosti do terajšieho času.

Úvod reči Concio Historico - Panegyrica de Sanctis Slavorum Apostolis, Cyrillo, \& Methodio vyjadruje aj prostredníctvom použitých deiktických prostriedkov snahu Juraja Fándlyho zainteresovat' na tom, o čom hovorí, poslucháčov, predstavit minulost', misiu Konštantína a Metoda ako súčasnú tému, aktuálnu pre národ aj dnes, pričom zdielanie poznatkov o minulosti vytvára povedomie spolupatričnosti, lebo to, o čom sa hovorí, je naša história, čo korešponduje so zisteným najvyšším zastúpením tvarov zámena NÁŠ spomedzi všetkých zámen v úvode reči Juraja Fándlyho.

\section{Komparácia tematizácie cyrilo-metodskej misie Juraja Fándlyho s riešením Jána Kollára a Jonáša Záborského}

Cyrilo-metodská misia sa tematizovala nielen v kázni Juraja Fándlyho, ale objavuje sa v kázňovej literatúre aj neskôr, v 19. storočí, tu pars pro toto zastúpenej dielom Jána Kollára a Jonáša Záborského, ktorí sa síce na rozdiel od Juraja Fándlyho nevenovali téme vo väčšom rozsahu, no interpretovali ju osobitým spôsobom.

Ján Kollár (1793 - 1852), básnik, propagátor myšlienky slovanskej vzájomnosti, bádatel’v oblasti slovanskej archeológie, filológie a mytológie, zberatel' ludovej slovesnosti, pôsobil ako dlhoročný kazatel' slovenskej evanjelickej cirkvi v Pešti (1819 - 1849). Tematizácia osobností Cyrila a Metoda sa objavuje konkrétne v Kollárovej dvojkázni prvýkrát publikovanej pod názvom Dobré vlastnosti národu slovanského. Dvoje kázaní od Jána Kollára (Pešt' 1822) a neskôr zaradenej do prvého zväzku Nedělní, svátečné i př́ležitostné kázně a řeči (Pešt 1831). V dvojkázni chápe Ján Kollár adresátov svojho kázania a aj sám seba ako súčast̉ národného spoločenstva Slovanov, založeného na spoločnej reči, etike a tradícii. Národ pomenúva tvarmi substantíva Slovan, ${ }^{7}$ no častejšie tvarmi adjektíva slovanský. V spojení s inými substantívami sa popri adjektíve slovanský (šest'krát) vyskytuje aj adjektívum slovenský (pätkrát). ${ }^{8}$ Pomerne vyrovnané zastúpenie adjektívnych tvarov slovanský a slovenský v spojení s konkrétnymi, jednotlivými javmi stojí oproti jednoznačnému uprednostneniu atribútu slovanský v spojení s celkom, s národom. Slovania sa majú podla Jána Kollára $(2009,415)$ vyznačovat nasledujúcimi piatimi vlastnostami: „Nábožnost, pracovitost, nevinná veselost, milování své reči a snášenlivost", ktoré sú v piatich častiach kázne jednotlivo vysvetlené a zdôvodnené. Zmienky o Cyrilovi a Metodovi sú súčastou argumentácie o dvoch vlastnostiach Slovanov, o ich nábožnosti a o láske k rodnej reči. ${ }^{9}$ Privlastnenie nábožnosti Slovanom zdôvodňuje Ján Kollár $(2009,416)$ historicky, na základe misie uskutočnenej Konštantínom a Metodom:

7 V substantívnom určení národa jednoznačne dominuje Slovan, len raz sa v poznámke pod čiarou ilustrujúcej národnú diskrimináciu nepoužíva všeobecné Slovan, ale konkrétnejšie Slováci: „Slovákưm se kazatelé a školmistři slovenští odebírajï (Kollár 2009, 428). Kollár reflektuje vlastnú kaplánsku skúsenost’ z Pešti, kritickú situáciu slovenského duchovného v národnostne heterogénnom prostredí. Kázeň Jána Kollára má nepochybene apologetický charakter, obraňuje národné záujmy (Kiss Szemán 2014, 27).

8 Príklad výskytu atribútu slovanský a slovenský: „slovanské mozole pracují i za jiné a pro jiné, slovanské ramena vzdělávají z vetši částky naše zahrady a vinice, slovenské ruky nesou z větši částky kosu na louky" (Kollár 2009, 418).

9 Láska k rodnej reči sa stala ústredným námetom d’alšej Kollárovej kázne Jak mnohé a svaté přičiny nás k tomu zavazují, aby sme i my tu řčc milovali, ve které jsme se zrodili. Kollár $(2009,408)$ sa tu zmieňuje aj o Cyrilovi, no jeho meno sa uvádza len v zátvorke: „Která řeč mezi nynějšími nejpředněji knihy Písma svatého $z$ mrtvého do živého jazyka, a to tak vlastně, tak zdařile preložila (Cyril), že se jí jiné reči ani jen 
„A když se světu záře krestanství zableskla, tedy slovanský národ nečekal, pokud by apoštolé a učitelé křestanského náboženstva náhodou $k$ němu přišli; ale on sám schválně poslal ze svého prostředku vyslance ku křestanưm do mesta Konstantinopole (roku 863), odkud navrátivše se přivedli sobě dva učitele křestanské do své vlasti, Cyrila totiž a Methodia, kteř́ někdy i naše předky křestili a semeno slova božího mezi nimi rozsívali." Cyrila a Metoda identifikuje Ján Kollár najprv konfesionálne, geograficky a temporálne, potom funkčne, rolovo (dva učitele) a nakoniec propriami (Cyrila totiž a Methodia), teda ukazuje na nich priamo. Kollár sa zameriava na náboženský rozmer misie Konštantína a Metoda, šírenie krestanstva medzi slovanským národom cez obrady (křestili) a slovo (semeno slova božího mezi nimi rozsívali). Kollár, hovoriac o minulosti Slovanov, použije deiktické MY zahrňujúce JA a VY len v prípade usúvztažňovania seba a poslucháčov kázne s predkami (naše předky), na druhej strane častejšie používané ON/ONI zvýrazňuje časovú dištanciu medzi aktuálnymi účastníkmi komunikácie a tými, o ktorých sa hovorí. Podobne sa na národ v minulosti ukazuje ako na neúčastníka komunikácie prostredníctvom ON/ONI aj v dalšej časti kázne, kde sa Kollár $(2009,420)$ vyjadruje o láske Slovanov k rodnej reči: „Jiní národové, když křestanské náboženstvo přijali, všickni v cizém nesrozumitelném jazyku služby své a pocty v chrámě vykonávali; sám národ slovanský v této věci výmínku učinil a Boha od počátku svým mateřským jazykem chválil; kterou svobodu on sobě zvláště od správcư církve vyjednal a ne bez obtížnosti chrániti hleděl. A který národ o to včasněji a snažněji pečoval, aby Písmo sv. ve své vlastní řeči čitati mohl? Ti jistí mužové, kteři křestanství $k$ nim donesli, museli jim hned i knihy biblické do slovanského jazyka překládati." V tejto časti kázne sa odkazuje na to, čo už bolo povedané, formulácia Ti jistí mužové sa odvoláva na predtým pomenované historické osobnosti, na Cyrila a Metoda. Kým v argumentácii o nábožnosti Slovanov upozornil Kollár na kristianizačný rozmer cyrilo-metodskej misie, tu sa zameral na ich slovesné dielo. Slovesná čast’ misie Konštantína a Metoda sa pre Kollára stáva dokladom vztahu Slovanov k rodnej reči, ked’ píše o nevyhnutnosti používat vlastný jazyk (museli jim hned i knihy biblické do slovanského jazyka prekládati).

Odlišnú podobu interpretácie cyrilo-metodskej misie zvolil Jonáš Záborský, slovenský spisovatel', dlhoročný farár v Župčanoch v náročnej pozícii konvertitu (z pozície evanjelického farára prestúpil na katolícke vierovyznanie) vydal zbierku kázní Múdrost života ve chrámových řečech pro všecky roku církevního př́ležitosti. Díl I. - II. (1853), v ktorej sa objavila aj cyrilo-metodská tematika, ${ }^{10}$ konkrétne v kázňach $\mathrm{Na}$ den zjevení Krista p. mudercưm a Na sv. Štefana Krále.

Záborského kázeň $\mathrm{Na}$ den zjevení Krista p. mudercưm $\mathrm{v}$ dvoch častiach vysvetluje tézu, že „Ježíš jest naozaj světlo a osloboditel pohanů. I. Světlo, pověvadž je vytrhnul z nevědomosti; II. osvoboditel, poněvadž zrušil mezi nimi porobu." (Záborský 2015, 67). Súčastou argumentácie o súvislosti medzi rozširovaním evanjelia a vzdelanosti, o podiele cirkvi na odstraňovaní nevedomosti v I. časti jadra kázne je aj zmienka o zakladajúcom význame cyrilo-metodskej misie pre vzdelanost’ na našom území: „První vírozvěstové naši, sv. Cyrill a Method, položili, právě v zemi otců našich, základ vzdělanosti pro celý slovanský národ, $k$ dyby dílo jimi započaté nebylo protrženo bývalo. Oni zdokonálili písmo pohanských předků našich, přeložili do řeči slovanské i písmo svaté i bohoslužebné knihy, zavedli, mimo obyčeje toho času, obřad národní a vymohli ku všeckému tomu přivolení od apoštolské stolice. Na neštěstí ale padlo právě v ten čas rozpolení mezi západní a východní církví, a zapř́ićinilo naše také rozštípení, mezi dvúma odpornými stránkami kolotání, rozličné proti nám pletichy, nepř́izně, nenávisti, na poli i církevním i světském. Tak se stalo, že úmysel svatých bratrů nebyl u nás napospol proveden, a že nás i v občanském životě zasáhly mnohé smutné osudy." (Záborský 2015, 67). Jonáš Záborský v kázni vyzdvihol predovšetkým vzdelávací rozmer cyrilo-metodskej misie, hovorí o význame misie

přirovnati nesměji pro nedostatek svatých, $k$ náboženstvu a ku přeložení Písma svatého nevyhnutlivě přináležejících slov, jak jsme to už výše podotkli?“.

10 Podla Petra Zubka $(2013,31)$ patril Jonáš Záborský k šíritelom kultu sv. Cyrila a Metoda. 
pre celý slovanský národ, viacnásobne upozorňuje na kontinuitu, prepojenie medzi Slovanmi v minulosti a súčasnými účastníkmi komunikácie prostredníctvom posesíva NAŠI, rovnaké usúvztažnenie bolo použité aj vo vzt̉ahu k Cyrilovi a Metodovi. Neostáva však len pri pozitívach, pripomína rozkol v cirkvi a jeho negatívne následky pretrvávajúce do súčasnosti.

V dalšej Záborského kázni, Na sv. Štefana Krále, sa zdôraznil krestanský rozmer misie Cyrila a Metoda. Nachádza sa tu len jedna zmienka o Cyrilovi a Metodovi, je súčastou exordia, úvodu, v ktorom sa podáva historický exkurz $\mathrm{k}$ počiatkom Uhorského královstva postaveného na krestanských základoch a s pomocou Slovákov a Moravanov. Záborský $(2015,371)$ o Štefanovi píše: „On získal, byv napréed sám r. 984 v Ostrihomě sv. Vojtěchem (Adalbertem), biskupem pražským, pokřestěn, národ mad’arský kř́ži, kterému naši předkové Slováci, byvšse sv. Cyrillem a Methodiem obráceni, vtedy už věrní byli, a skrze kterých, pomocí toho, „nímž králové panují, "Přísl. 8, 15. se mu to jedině podařilo. Mad’aři totižto postavili se novému náboženství zbrojnou rukou oproti, a sv. Štefan jen prostředkem zmužilých Slováků a Moravanů mohel vůdce jejích Kupu, zvláště ve krvavé bitce u Hronu, potřeti.“. Vo formulácii je zrejmý Záborského zámer zdôraznit zásluhy Slovákov na budovaní Uhorského královstva, pracuje s významovým radom Slováci - cyrilo-metodská misia krestanstvo - vznik Uhorského královstva.

Jonáš Záborský zvolil „hlibavý, biblicko-filozofický a psychologický“ spôsob kázania (Zubko 2013, 31), ktorý sa prejavil v premyslenej argumentácii a informačnú nasýtenost̉ reči podčiarkuje v prípade analyzovaných textov sprostredkúvanie historického kontextu témy (využitie presnej časopriestorovej lokalizácie udalostí, práca s propriami). Téma cyrilo-metodskej misie netvorí dominantu ani v jednej z rečí Jonáša Záborského, ide len o ojedinelé zmienky, no sú dôležitou súčastou výkladových pasáží s funkciou posilnit argumentačnú presvedčivost’ Záborského kázania.

Výsledky analýzy úvodu kázne Juraja Fándlyho v porovnaní s kázňami Jána Kollára a Jonáša Záborského vedú $\mathrm{k}$ nasledujúcim zisteniam: cyrilo-metodská tematika je v kázňach z obdobia národného obrodenia Slovákov (z konca 18. a z 19. storočia) predovšetkým súčastou diskurzu o národe, pričom koncepcia národa závisí od ideologickej orientácie autora, národ sa poníma inak medzi bernolákovcami (tu pars pro toto zastúpenými Jurajom Fándlym) a inak medzi prívržencami idey slovanskej vzájomnosti (Ján Kollár). Ján Kollár verbalizuje význam cyrilo-metodskej misie pre celý slovanský národ na rozdiel od Juraja Fándlyho, ktorý hovorí o význame pre slovenský národ. Oba prístupy možno vidiet’ u Jonáša Záborského, ktorý v reči Na den zjevení Krista p. mudercům píše o cyrilo-metodskej misii k Slovanom a v reči $\mathrm{Na}$ sv. Štefana Krále píše o cyrilo-metodskej misii k Slovákom, jeho prístup je menej než v prípade Juraja Fándlyho alebo Jána Kollára zviazaný s konkrétnou ideológiou a mení sa podla intencie kázne, podla jej hlavnej témy. Autori kázní sa líšia aj v konfesionálnom rozmere, Juraj Fándly hovorí o katolicizme aj v súvislosti s misiou Cyrila a Metoda (katolickég Wíri, na kteru, gích títo dwa swatí Učiteli obrátili), Ján Kollár explikuje seba a poslucháčov ako evanjelikov a v súvislosti s cyrilo-metodskou misiou píše všeobecnejšie o jej krestanskom rozmere (dva učitele křestanské), Jonáš Záborský zdôrazňuje fakt, že v čase pôsobenia Cyrila a Metoda sa začal rozkol v cirkvi, upozorňuje na ruptúru medzi ich pôsobením a následným vývinom už v rámci Uhorského královstva - na rozdiel od Juraja Fándlyho, ktorý opakovane hovorí o kontinuite, pokračovaní, nasledovníkoch. Deiktické ukazovanie na Cyrila a Metoda sa deje prostredníctvom ONI, len Juraj Fándly Cyrila a Metoda aj bezprostredne oslovuje prostredníctvom VY (Blahoslawení ste wi naší swatí Apoštoli) a vždy ich usúvztažňuje s inkluzívnym MY prostredníctvom NAŠI (naších dňešních slowenskích Apoštolow), čo sa naopak vôbec nevyskytovalo v kázni Jána Kollára, kde sa o misii Cyrila a Metoda píše ako o historickej udalosti a kontinuita sa vztahuje len na národ (naše předky). Postoj autora, jeho konfesionálne, ideologické presvedčenie ovplyvnilo spôsob tematizácie cyrilo-metodskej misie a interferovalo s volbou deiktických prostriedkov ukazujúcich na svätého Cyrila a Metoda aj na účastníkov komunikácie. 


\title{
REFERENCES
}

Fándly, Juraj. 1796. Príhodné a Swátečné Kázňe, od mnohowel’ebného Pána Fándli Gura naháčského Farára zložené ai kázané. Druhí Zwazek. Trnava.

Genette, Gérard. 1997. Palimpsests. Literature in the Second Degree. Lincoln - London.

Hirschová, Milada. 2013. Pragmatika v češtině. Praha.

Kiss Szemán, Róbert. 2014. Slovanský Goethe v Pešti. Ján Kollár a národní emblematizmus středoevropských Slovanů. Praha.

Kollár, Ján. 2009. Dielo. Bratislava.

Sväté písmo. 2007. Sväté písmo Starého i Nového zákona. Trnava.

Záborský, Jonáš. 2015. Múdrosť života ve chrámových řečech. Bratislava.

Zubko, Peter. 2013. Kňaz nie každodenný. Jonáš Záborský v službe Košickej diecézy. Bratislava.

\begin{abstract}
SUMMARY: THE DEICTIC EXPRESSIONS IN UPDATING THE THEME OF THE CYRIL AND METHODIUS MISSION IN THE BEGINNING OF THE SERMON WRITTEN BY JURAJ FANDLY. The study analysis the beginning of the sermon written by Juraj Fandly Concio Historico - Panegyrica de Sanctis Slavorum Apostolis, Cyrillo, \& Methodio from the focus of distribution of deictic expressions in the composition parts of sermon's beginning and the subject of the sermon - the Cyril and Methodius mission. The deictic expressions are situated especially on the beginning and ending of the composition parts of sermon. Personal deixis encodes the constant participants' roles in the sermon and shows itself typically in personal and possessive pronouns. The role of the speaker has only preacher, with the pronoun "I" Juraj Fandly refers to himself and the second plural personal pronoun includes the addressees as listeners into the speech event. Minimum of singular second person verbs means that Juraj Fandly addressed his sermon to the national community not to individual addressee, which confirms the fact that the most used personal pronouns were "we" and "you" (plural). The most used possessive pronoun was "our", which means, that the most important thing for Juraj Fandly is presents the Cyril and Methodius mission like part of our history and in the same time like very actual present subject used temporal deixis expressed in time adverbials like "now" or "up to now". Finally, the interpretation of the Cyril and Methodius mission by Juraj Fandly is compared with the interpretations written by Jan Kollar and Jonas Zaborsky.
\end{abstract}

doc. PhDr. Gabriela Mihalková, PhD.

University of Presov

Faculty of Arts

Institute of Slovak and Media Studies

17. novembra 1

08001 Prešov

Slovakia

gabriela.mihalkova@unipo.sk 